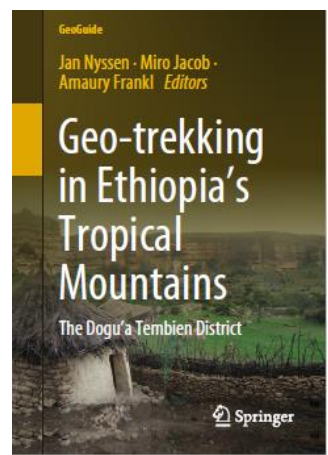

Aerts R., Lerouge F., November E. 2019. Birds of forests and open woodlands in the highlands of Dogu'a Tembien. Pp. 261-278 in Nyssen J., Jacobs M., Frankl A. (Eds.) Geo-trekking in Ethiopia's Tropical Mountains. The Dogu'a Tembien District. GeoGuide. Springer nature Switzerland AG. https://doi.org/10.1007/978-3-030-04955-3 17

Authors whose work is accepted for publication in a non-open access Springer book may deposit their author's accepted manuscript (AAM) in their institutional or funder repository, provided that the following conditions are observed. The author's accepted manuscript is the version of the book manuscript accepted for publication after peer review, but prior to copyediting and typesetting. The self-archived AAM should not include any changes made after the point of editorial acceptance. Any necessary amendments or corrections to article content should be made to the version of record (VoR) on the publisher platform.

To access the final edited and published work see https://doi.org/10.1007/978-3-030-04955-3

(C) 2019. This manuscript version is made available under the CC-BY-NC-ND 4.0 license http://creativecommons.org/licenses/by-nc-nd/4.0/

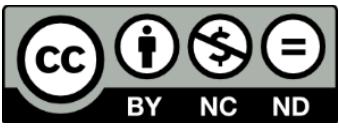




\section{Birds of forests and open woodlands in the highlands of Dogu'a Tembien}

32 Raf Aerts, University of Leuven, Belgium

33 Frederik Lerouge, PXL University College, Belgium

34 Eva November, Royal Museum of Central Africa, Belgium

36 The landscape in Dogu'a Tembien, in the northern highlands of Ethiopia, is a mosaic of

37 cropland, woodland and evergreen scrub with isolated patches of dry forest. Ethiopia is endowed

38 with an exceptionally rich fauna and flora, and is a global hotspot of biodiversity and endemicity.

39 In Ethiopia and Eritrea, 872 bird species occur, representing $39 \%$ of the bird species of Africa

40 and including 32 endemic species. Likewise, the forest-woodland-grassland complex in Dogu'a

41 Tembien is the habitat of a rich and interesting yet relatively underexplored bird fauna with

42 several endemic and biome-restricted species. In this chapter, we will look at birds in forest

43 fragments and open woodland of varying ecological quality, in particular church forests, grazing

44 exclosures and grazed woodland. We demonstrate that birds contribute substantially to the

45 cultural ecosystem services of the landscape by providing a high ecotourism potential.

\section{$47 \quad 20.1$ Birding Habitats in Dogu'a Tembien}

48 According to the most recent classification of vegetation in Ethiopia by Friis et al., the potential

49 natural vegetation of the Ethiopian highlands between 1800 and 3000 m altitude is "dry

50 evergreen montane forest and grassland complex" in areas with rainfall below $1700 \mathrm{~mm}$ per

51 year. This dry evergreen montane forest can be subdivided in a number of subtypes based on 
52 differences in the dominance of the indigenous coniferous species Afrocarpus falcatus and

53 Juniperus procera and in the relative abundances of grass, shrubs or broadleaved trees present in

54 the forest, and it can structurally vary from grasslands with shrubs and trees to closed-canopy

55 forest. Remnants of natural forests occur in isolated patches and are associated with wooded

56 grasslands, Acacia woodland and evergreen scrub. The forests are primarily "dry single-

57 dominant Afromontane forest of the Ethiopian highlands" with Juniperus procera and African

58 wild olive (Olea europaea ssp. cuspidata) as the most characteristic species (see Chapter 16 for

59 an overview of Afromontane forest types). Juniperus has become very rare throughout the

60 landscape but the wild olive can still be found in forests, in villages and sometimes as remnant

61 tree in the landscape. Wild olive is often the dominant component of "church forests" (Chapter

62 16). Church forests are small patches of forest, on average $\sim 2.5$ ha in size, that surround

63 Ethiopian Orthodox churches and that are protected because of the spiritual, cultural and

64 aesthetic values the local communities attach to these forests (Photo 20.1 and photos in Chapter

65 16). These forests offer unique resources to birds, such as food, shelter, shade, nesting sites and

66 water, and are the prime birdwatching habitat of the area. Prior permission to visit these church

67 forests and other sacred sites should be sought from the local priests; a support letter in Tigrinya

68 from a local official office may be extremely helpful. Other habitats worth investigating include

69 open woodlands associated to river gorges, hezaeti spare grazing lands and in particular

70 exclosures, formerly degraded land where open woodland of small shrub and tree species has

71 regenerated following the exclusion of livestock grazing and wood cutting (see Chapter 18).

72 Also a number of small-scale landscape elements, embedded in agricultural land or in those open

73 woodlands, are usually interesting in terms of avifauna; such landscape elements include

74 Euphorbia hedgerows, stone mounds (for raptors, see Chapter 21), microdams and in particular 
75 isolated fig trees, especially when bearing fruits. The area lies within the internationally

76 recognized Endemic Bird Area 'Central Highlands' of Ethiopia (EBA 115).

\subsection{Bird Survey}

To provide evidence for the bird conservation value of isolated forests and grazing exclosures, we surveyed bird species in a landscape mosaic of approximately $5 \times 10 \mathrm{~km}^{2}$ that consisted of

81 evergreen scrub and woodland, cropland and 10 dry Afromontane forest fragments in the Geba

82 river catchment $\left(13^{\circ} 37^{\prime} \mathrm{N}, 39^{\circ} 21^{\prime} \mathrm{E}\right.$; half-degree square or 'tetrad' $23 \mathrm{c}$ in the Birds of Ethiopia 83 and Eritrea atlas) in Central Tigray, northern Ethiopia, $20 \mathrm{~km} \mathrm{NW}$ of the regional capital Mekelle 84 and at an elevation of 1800-2000 m. The study was designed to determine bird species

85 community compositions of forest fragments, grazing exclosures and grazed open woodland and to assess whether there are forest-dependent birds that use exclosures and grazed woodland as

87 additional habitat. The small forest fragments (0.4-21 ha in size) consisted of dry Afromontane

88 forest with some fragments near water dominated by winter thorn (Faidherbia albida) and white 89 stinkwood (Celtis africana), and other, drier, fragments by olive, Acacia and the bushwillow

90 Combretum collinum (Photo 20.1). The exclosures and grazing lands consisted of Acacia

91 woodland with evergreen scrub species such as Euclea racemosa and Aloe macrocarpa. The

92 study was carried out during the cold rainy season (from 26 July to 15 October 2004), when

93 Palearctic migrant species were present. We conducted 277 one-hour timed species counts in ten

94 forest fragments (188 counts), five exclosures (57 counts) and three grazing lands (32 counts). 
Checklists, field guides and distribution atlases of bird species traditionally make use of

99

100

101

102

103

104

105

106

107

108

109

110

taxonomic or systematic lists of bird species, in which bird species are placed in a sequence that reflects the evolutionary history of birds. The nomenclature and the species list at the end of this chapter follow the nomenclature and sequence adopted by "Birds of Ethiopia and Eritrea. An atlas of distribution". The sequence and nomenclature in this authorative atlas for Ethiopia is an adaptation of the sequence and nomenclature of the Howard and Moore Complete Checklist of the Birds of the World, which is relatively stable in terms of nomenclature for Ethiopia. Because of the many uncertainties of which taxa are currently recognized as distinct species and because of the ongoing process of splitting species, which may result in additional endemics or nearendemics in the future, some names used in this chapter may differ from names used in other publications. The number preceding each species in the species list in the Appendix is the sequence number of the bird species in the first edition of "Birds of Ethiopia and Eritrea. An atlas of distribution".

\subsection{Bird Communities}

A total of 170 bird species were recorded at 18 sites (at least 551 bird species occur in Tigray but these numbers include lowland bird species and species of habitats that were not surveyed in this study such as marshes and ponds). Forest sites (133 species) and non-forest sites (i.e. exclosures and grazed woodland) (94 species) shared 81 species (55\%). This means that 52 species (31\%) of the recorded bird species were only observed in the small forest fragments in the study area. We found three distinct forest bird communities: birds of dry Afromontane forest in the vicinity 
119 of water (6 sites, 119 species), birds of other (more open) dry Afromontane forest (4 sites, 121

120 species), and birds of Acacia woodland and evergreen scrubland (all exclosures and grazed

121 woodland sites, 8 sites, 84 species). Overall, the recorded bird community was representative of

122 Afrotropical highland open forest and woodland with a high proportion of competitive generalist

123 species (31\%). The most common species across all sites included Speckled Pigeon, Dusky

124 Turtle Dove, Laughing Dove, Grey-backed Camaroptera, Common Bulbul, Blue-eared Glossy

125 Starling, Variable Sunbird, Grey-headed (Swainson's) Sparrow, Baglafecht Weaver and Red-

126 cheeked Cordon-bleu (often spotted within the first ten minutes of a visit to a site).

127

\subsection{Biome-Restricted, Endemic and Specialty Bird Species}

129 Twenty-four species (14\%) were biome-restricted. Eighteen species belonged to the Afrotropical 130 Highland Biome (AHB), an assemblage that contains 56 bird species in Ethiopia. These species 131 typically occur in the dry evergreen montane forests of the highland plateau but can also occupy 132 other habitats. All AHB species are species of interest for the area. Wattled Ibis (ENDEMIC, an 133 endemic of Ethiopia and Eritrea) can be found feeding in wet grassland and open woodland (and 134 also occurs in cities). Black-winged Lovebird (ENDEMIC), Banded Barbet (ENDEMIC), Gold135 mantled (Abyssinian) Woodpecker (ENDEMIC), Montane White-eye (endemic to high mountains 136 of Northeast Africa), Rüppell's Robin-Chat, Abyssinian Slaty Flycatcher (ENDEMIC) and 137 Tacazze Sunbird are found in evergreen forest, mountain woodlands and areas with scattered 138 trees including fig trees, euphorbias and junipers. Erckel's Francolin (Abyssinian near endemic), 139 Dusky Turtle Dove, Grey-headed (Swainson's) Sparrow (Abyssinian near-endemic), Baglafecht 140 Weaver, African Citril, Brown-rumped Seedeater (Abyssinian near-endemic) and Streaky 
141 Seedeater are common Afrotropical breeding residents of woodland edges, scrubland and forest 142 edges. White-billed Starling (ENDEMIC) and Little Rock Thrush (an endemic of Arabia and 143 Northeast Africa) can be found on steep cliffs and White-collared Pigeon (ENDEMIC) in gorges 144 and rocky places but also in towns and villages.

A number of enigmatic species of the AHB were not recorded during the formal survey but were recorded in other forests in the area, most notably White-cheeked Turaco (a near endemic

147 of Ethiopia and Eritrea) and Abyssinian (Black-headed Forest) Oriole (ENDEMIC) (both recorded 148 in Abiy Dur ('Large Forest') in Waseya (Photo 16.10), see recommended birdwatching sites). 149 Yellow-fronted Parrot (ENDEMIC) and Abyssinian Catbird (ENDEMIC) were not recorded but 150 could be present in dense bushy areas and Acacia-Juniper forest. Both bird species have been 151 confirmed in adjacent half-degree squares (Yellow-fronted Parrot: tetrads 23a, 23d; Abyssinian 152 Catbird tetrads 23b, 31b), some of which overlap with the National Forest Priority Areas and 153 Important Bird Areas Desa'a Forest (IBA2) and Hugumburda and Grat-Kahsu Forests (IBA5). Five species belonged to the Somali-Masai Biome (SMB). Hemprich's Hornbill (Photo 155 20.2) and White-rumped Babbler (Abyssinian near-endemic) are found in bushland, scrubland 156 and dense secondary forest, often near cliffs, gorges or water. Somali (Chestnut-Winged) 157 Starling and Rüppel's Weaver are found in bushy and shrubby areas. The Somali Starling may 158 be confused with the much more common Slender-billed Starling and the status of the species in 159 Dogu'a Tembien is unclear. Black-billed Wood-Hoopoe is an Abyssinian near-endemic of 160 Acacia woodland and has some red at the base of the bill or an entirely red bill in this area. Two 161 species belonged to the Sudan-Guinea Savanna Biome (SGSB). Green-Backed Eremomela and 162 Chestnut-crowned Sparrow-Weaver are species of Acacia and Combretum woodland. 
Finally, we recorded a number of interesting species that are neither endemic nor biome-

restricted but that have restricted ranges or that can be more easily seen in Ethiopia than elsewhere in their range. Abyssinian Roller (Photo 20.3) is an Ethiopian relative of Lilacbreasted Roller, which is an intra-tropical breeding migrant of south and east Africa, and of European Roller, an uncommon Palearctic passage migrant. Black-billed Barbet, Yellowbreasted Barbet (Photo 20.4) and Grey-headed Batis are species from the Sahel and Northern Africa but also occur in Acacia woodlands in the area.

\subsection{Birds Only Recorded in Forest Fragments}

Fifty-two bird species (36\%) were only observed in the forest fragments during the formal bird survey. Some of these species are indeed forest-dependent bird species but many other species in this group also occur in gardens, cultivated land or other habitats that were not surveyed. The majority of bird species in this group feeds on invertebrates or has an omnivorous diet that includes invertebrates, fruits and seeds. Highlights in this group include various kingfishers, barbets and woodpeckers. In the generally dry landscape, the observation of kingfishers often comes as a surprise, but Grey-headed Kingfisher, Striped Kingfisher and African Pygmy Kingfisher are species that not necessarily depend on the proximity of water. Grey-headed and African Pygmy Kingfisher are outstanding birds to observe, the former with a grey head and heavy red bill, the latter a delicate, minute kingfisher with pink cheeks, blue crest and rufous underparts. The endemic Banded Barbet and Black-billed Barbet feed on insects and fruits, can often be seen in the vicinity of fruiting trees and like all barbets feature a heavy bill surrounded by modified feathers called bristles, and a distinctive bill notch and tooth in Banded Barbet. 
185 Red-fronted Tinkerbird is a smaller barbet which is reported to be less sensitive to forest

186 disturbance than other barbets. The heavily-striped Nubian Woodpecker and the red-rumped,

187 endemic Gold-mantled or Abysinnian Woodpecker are obviously species of forest and

188 woodland. Euphorbia trees are a good spot to look for these species.

Other notable birds of interest that were only observed in forests during the formal survey

include Bruce's Green Pigeon, a colorful, stout pigeon almost exclusively found in the canopy of

191 fruiting fig trees where it is well camouflaged; Abyssinian Roller (Photo 20.3), a large bird with

192 brilliant blue wings and long tail streamers which is often seen perched high on trees or posts

193 along roads; African Paradise Flycatcher, a striking rufous and/or white bird with black crested

194 head, a blue eye ring and males have very long tail streamers, which can be rufous or white (also

195 frequently seen in gardens); Tacazze Sunbird, a large sunbird often found near flowers, including

196 Aloe flowers, the males with long tail streamers; and Village Indigobird, an interspecific brood

197 parasite of Red-billed Firefinch. Many more interesting species can be observed in the isolated

198 forests, but many of the most interesting birds such as the endemic and AHB species were

199 recorded with relatively low frequencies (see Appendix). Visiting different forests and visiting

200 forests more than once are the best options to optimize your birdwatching experience in the area.

\subsection{Birds of Forest and Other Woodland Habitats}

203 Forty-five bird species (26\%) occurred in all surveyed habitat types during the formal survey, i.e.

204 in forests, exclosures and in grazed open woodland. Most species were typically birds of

205 grassland and savanna with the majority of bird species feeding on invertebrates and/or seeds.

206 Highlights among these forest and open woodland species are the endemic parrot Black-winged 
Lovebird (easily heard because of its high-pitched screeching and often found nesting in euphorbias; also feeds on the ground), Hoopoe (Photo 20.5), Hemprich's Hornbill (Photo 20.2) and Abyssinian Ground Hornbill. Hoopoe (Photo 20.5) is a strongly territorial species when nesting, with a prominent crest that can be fanned. The Ground Hornbill (locally called Abo Gumbah, which translates as 'bowed father') is a tall $(>100 \mathrm{~cm})$ black bird with bare blue skin around the eye and throat, a short open hollow chamber or casque at the top of the heavy bill, exceptionally long eye-lashes, and in males, a patch of bare red skin on the throat. The birds can fly and roost in (isolated) trees but are more often seen on the ground, in pairs or small (family) groups, in grassland and farmland. Among the smaller common generalist species, Montane White-eye is a brown-yellowish bird with characteristic bright white eye-ring, often occurring in (mixed) flocks and in juniper trees; Variable Sunbird is a small nectar-feeding bird that hovers like a hummingbird with glossy green head and purple breast band in the males; Northern Red Bishop is a small species of tall grassland with striking pure orange mantle and red tail coverts (when in breeding plumage); and Red-billed Firefinch and Red-cheeked Cordon-Bleu are petite but colorful species associated to farmland and villages.

Twenty-nine bird species (17\%) were recorded in forests and in exlosures but not in the grazed open woodland during the formal survey. These bird species could be forest-dependent species that tolerate disturbance and use the exclosures as sub-optimal forest habitat (e.g. for feeding but not for breeding). Alternatively, these bird species could be species of open woodland that have invaded the dry forest following fragmentation, isolation and internal degradation of the forest, or these species are adapted to forest and open woodland but avoid grazed woodland because it lacks certain resources such as shade. The diet of $50 \%$ of the birds in this group consists of invertebrates. Highlights in this group include Greyish Eagle-Owl 
230 (recently split from Spotted Eagle-Owl and often found in densly wooded gullies that run

231 through exclosures) (Photo 20.6); Abyssinian (Montane or Mountain) Nightjar (Photo 20.7), a

232 well-camouflaged bird that roosts in a concealed position on the ground and rocky outcrops

233 during the day; Blue-breasted Bee-eater (Photo 20.8), a green bee-eater with white cheeks,

234 rufous wings and purple breast band that often occurs in small groups and that after flying out

235 from a perch to hawk for insects usually lands in exactly the same spot (aerial sallies); Yellow-

236 breasted Barbet (Photo 20.4), a large barbet with yellow head and red bill associated to dry

237 acacia woodlands with dry river banks or termite mounds; and Scarlet-chested and Mariqua

238 Sunbird. Nightjars are notoriously difficult to identify but the species recorded in the area occurs

239 at higher elevation and has more extensive white in the outer tail than the very similar Sombre

240 (Dusky) Nightjar.

Only thirteen bird species (6\%) occurred in exclosures and/or woodland but were never

242 observed in forests. Highlights are Rufous-crowned (Purple) Roller, a roller of dry areas with

243 tall trees (which was recorded in exclosures only) and Black-bellied Bustard, a large ground-

244 dwelling bird of tall grassland and savanna that appears to arrive in dry areas after rains.

\section{Box 1 Some Remarkable Bird Behavior}

A number of bird species that occupy forests and open woodland habitat in Dogu'a Tembien

deserves to be mentioned here because of their interesting behavior. Clumping. Speckled

Mousebird and Blue-naped Mousebird move through fruiting trees like squirrels and form 
incubating adults (co-operative breeding). Duetting. Tropical Boubou is a fairly common species of woodland understorey and scrub vegetation with a distinct call which can be compared to the sound of a rusty swing. The call is actually a duet, initiated by one bird (usually the male), immediately followed by a different call of another, nearby bird (antiphonal duet). There are many different types of duetting: birds may use the same or different calls, call simultaneously, alternately or unsynchronised, and the duet may sound like a single bird calling or not. Other species in the area that engage in duetting include Helmeted Guineafowl (antiphonal, different calls, female initiates, only when breeding), Hamerkop (alternating or simultaneous, similar calls), Greyish Eagle-Owl (antiphonal, similar calls, only occasionally and probably to seek contact, Photo 20.6), Grey-headed Kingfisher (simultaneous, similar calls, in breeding or territorial display), all hornbills (simultaneous or synchronised, similar calls), Yellow-breasted Barbet (unsynchronised, Photo 20.4), Black-headed Bush-Shrike (Tchagra) (simultaneous or alternating, male initiates), and Mocking Cliff-Chat (occasional, alternating, similar calls).

Lekking. Pin-tailed Whydah (Photo 20.9) is an inter-specific brood parasite, mainly on waxbills (e.g. Crimson-rumped Waxbill and Yellow-bellied Waxbill). In the breeding season, the males have a colorful breeding plumage with long black tail streamers (the four central tail feathers) and gather in competitive breeding displays. Wing-flashing. Namaqua Dove has a long tail and the males have an orange bill and black forehead, chin and throat. The male Namaqua Dove flashes its rufous wings to deter predators and in courtship display (Photo 20.10). 
275 Our data shows that exclosures have an important conservation value for birds of forest and 276 woodland habitat, but also that forests are the best sites for conservation of birds and for 277 birdwatching. Small landscape elements with woody vegetation in the immediate vicinity of 278 such forests, such as isolated remnant trees or wooded gullies are also interesting for

279 birdwatching. We suggest a few sites that are interesting for birdwatching (* highly

280 recommended) and once again stress that it is important to seek prior informed consent to visit 281 church forests and other holy sites including holy waters. Additional coordinates of sites worth 282 exploring for birds are given in the Supplementary Information.

Dry Afromontane forests higher than $2000 \mathrm{~m}$

285 Mai Be’ati (13³8’51.5’N, 39¹3’11.9’E), 6 ha, perimeter $1.2 \mathrm{~km}, 2271-2338 \mathrm{~m}$ (Photo 16.1).

286 Church forest at the base of a limestone cliff with a perennial spring and an adjacent grazing 287 exclosure with rocky gullies. Located $1 \mathrm{~km}$ from the main Mekelle-Hagere Selam road (100 m 288 descend). Good view in the forest canopy (mostly olive but also large figs and other species) 289 from the limestone cliff; also good site to spot Rock Hyrax.

290 Haragua $\left(13^{\circ} 40^{\prime} 46.1^{\prime} \mathrm{N}, 39^{\circ} 09^{\prime} 32.5^{\prime \prime} \mathrm{E}\right), 13$ ha, perimeter $2.6 \mathrm{~km}, 1973-2229 \mathrm{~m}$ (Photo 16.9). 291 Fairly large church forest $3.6 \mathrm{~km} \mathrm{NNW}$ of Hagere Selam. The church and a number of other 292 buildings are located at the base of a limestone cliff. Large isolated olive trees on the plateau 293 east of the forest are also interesting to look for birds. 
294 Waseya* $\left(13^{\circ} 40^{\prime} 47.3^{\prime \prime} \mathrm{N}, 39^{\circ} 07^{\prime} 26.8^{\prime \prime} \mathrm{E}\right), 49$ ha, perimeter $3.4 \mathrm{~km}, 2014-2348 \mathrm{~m}$ (Photo 16.10).

295 Large church forest and exclosure $5.5 \mathrm{~km} \mathrm{NW}$ of Hagere Selam. The church is located at the

296 lower end of the forest. A rocky gully bisects the entire forest. Key species include Black-

297 winged Lovebird, White-cheecked Turaco, Greyish Eagle-Owl, Black-billed Barbet, Hemprich's

298 Hornbill and Abyssinian (Black-headed Forest) Oriole.

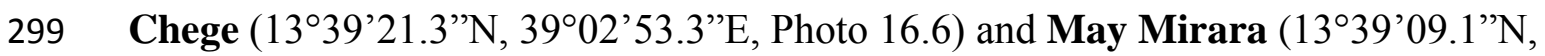

$30039^{\circ} 04^{\prime} 09.8^{\prime \prime} \mathrm{E}$, Photo 16.11), like Waseya, cover steep west-facing slopes and extend from the 301 edge of the plateau towards the lower limit of the dry evergreen montane forest and grassland 302 zone. Their bird fauna remains to be explored.

Dry Afromontane forests, lower than $2000 \mathrm{~m}$

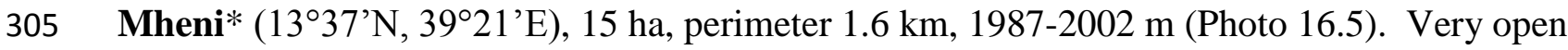
306 Acacia-Olea woodland with a number of larger trees and euphorbias in and near the central 307 church compound, $0.6 \mathrm{~km}$ from the main Mekelle-Hagere Selam road, $3.7 \mathrm{~km}$ beyond the Geba 308 river bridge. Tall grass grows in between the trees in the rainy season. Key species include 309 Black-winged Lovebird, Greyish Eagle-Owl, Hoopoe, Black-billed Wood-Hoopoe, Banded 310 Barbet, Nubian and Gold-mantled (Abyssinian) Woodpecker, Grey-headed Batis and Montane 311 White-eye. The adjacent hezaeti spare grazing land is a good site for Clapperton's Francolin, 312 Black-bellied Bustard, and Red-backed Shrike, at least during the tall grass season.

313 Geramesagu $\left(13^{\circ} 36^{\prime} \mathrm{N}, 39^{\circ} 20^{\prime} \mathrm{E}\right), 5$ ha, perimeter $1.0 \mathrm{~km}, 1946-1973 \mathrm{~m}$. Very open Acacia314 Olea woodland with a central grassy area, and a number of church buildings in the southern edge 
315 of the forest, $1.6 \mathrm{~km}$ from the main Mekelle-Hagere Selam road, $3 \mathrm{~km}$ beyond the Geba river

316 bridge. Species composition is similar to Mheni.

317 Sesemat* $\left(13^{\circ} 37^{\prime} \mathrm{N}, 3^{\circ} 1^{\prime} \mathrm{E}\right), 3 \mathrm{ha}$, perimeter $1.5 \mathrm{~km}, 1978-2044 \mathrm{~m}$. Wooded gully and two

318 isolated patches of more or less dense olive woodland, $2.3 \mathrm{~km} \mathrm{~S}$ of Enda Maryam Tucul. Key

319 species include Black-winged Lovebird, Blue-breasted Bee-eater, Hemprich's Hornbill, Black-

320 billed Barbet, Gold-mantled (Abyssinian) Woodpecker, African Paradise-Flycatcher and

321 Montane White-eye. At dusk the forest and surrounding grazing land are good sites to see

322 Spotted Hyena.

323 Minta $\left(13^{\circ} 40^{\prime} \mathrm{N}, 39^{\circ} 21^{\prime} \mathrm{E}\right), 3 \mathrm{ha}$, perimeter $1.2 \mathrm{~km}, 1964-2000 \mathrm{~m}$. Wooded gully and small

324 Acacia-Olea woodland, 7 km NE of Enda Maryam Tucul (Photo 20.1; Photo 16.4). Key species

325 include Clapperton's Francolin, Eastern Grey Plantain-eater, Black-billed Wood-Hoopoe,

326 Hemprich's Hornbill, Red-billed Hornbill, Banded, Black-billed and Yellow-breasted Barbet,

327 Grey-headed Batis and Northern Black Tit.

328 Three additional church forests, located in Enderta, are worth visiting en route to Dogu'a

329 Tembien when leaving by car from Mekelle: the church forest and waterfall of

330 Romanat* $^{*}\left(13^{\circ} 34^{\prime} 31.5^{\prime} \mathrm{N}, 3^{\circ} 25^{\prime} 08.7^{\prime \prime} \mathrm{E}\right)$; and the church forests of Chenferes* $\left(13^{\circ} 36^{\prime} 41.1^{\prime \prime} \mathrm{N}\right.$,

$\left.33139^{\circ} 26^{\prime} 10.1^{\prime \prime} \mathrm{E}\right)$ and Amne Ayesgi (13³6’49.4”N, 39²5’35.4”E) and the Faidherbia gallery

332 running between these two patches. Key species of Romanat include Tawny Eagle, Bruce's

333 Green Pigeon, Grey-headed Kingfisher, Black-billed Barbet, Violet-backed Starling and White-

334 billed Starling. Key species of Chenferes, Amne Ayesgi and the Faidherbia gallery include

335 Black-winged Lovebird, Abyssinian Nightjar, Blue-naped Mousebird, Abyssinian Roller, Grey- 
336 headed Kingfisher, Blue-breasted Bee-eater, Black-billed Wood-Hoopoe, Black-billed Barbet,

337 Yellow-breasted Barbet, White-billed Starling and Red-billed Oxpecker.

338

339 Supplementary Information

340 Google Earth KMZ file containing locations with potential birdwatching interest.

341

342 References

343 Aerts R, Lerouge F, November E, Lens L, Hermy M, Muys B (2008) Land rehabilitation and the

344 conservation of birds in a degraded Afromontane landscape in northern Ethiopia. Biodiversity

345 and Conservation 17:53-69

346 Ash J, Atkins J (2009) Birds of Ethiopia and Eritrea. An atlas of distribution. Christopher Helm,

347 A\&C Black Publishers Ltd, London.

348 Behrens K, Barnes K, Boix C (2010) Birding Ethiopia. A guide to the country's birding sites.

349 Lynx Edicions, Barcelona.

350 Carnaby T (2008) Beat about the bush. Birds. Jacana Media, Johannesburg.

351 Friis I, Demissew S, van Breugel P (2010) Atlas of the potential vegetation of Ethiopia. Biol.

352 Skr. Dan. Vid. Selsk. 58:1-307

353 Sinclair I, Ryan P (2003) Birds of Africa south of the Sahara. Struik Publishers, Cape Town. 
354 Sodhi NS, Sekercioglu CH, Barlow J, Robinson SK (2011) Conservation of Tropical Birds.

355 Wiley-Blackwell, Oxford, UK.

356 Tilahun S, Edwards S, Gebre Egziabher TB (Eds) (1996) Important Bird Areas of Ethiopia. A

357 first inventory. BirdLife International and Ethiopian Wildlife and Natural History Society, Addis

358 Ababa.

359 Urban E, Brown L (1971) A checklist of the birds of Ethiopia. Addis Ababa University Press, 360 Addis Ababa

361 Van Perlo B (1995) Birds of Eastern Africa. HarperCollinsPublishers Ltd, London. 

woodland (G) in Dogu'a Tembien in northern Ethiopia.

366 The species are listed with the following information:

367 Sequence number in "Birds of Ethiopia and Eritrea. An atlas of distribution"; principal English

368 vernacular name (common name) (photograph number); scientific name; $E$ or $P$ to indicate

369 whether the species is endemic to the Abyssinian plateau (Ethiopia and Eritrea) or a Palearctic

370 migrant; AHB, SMB or SGSB to indicate whether the species is a biome-restricted species of

371 the Afrotropical Highlands Biome, the Somali-Masai Biome, or the Sudan-Guinea Savanna

372 Biome; frequencies derived from our suvey, for forest (F), exclosure (EX) and grazed woodland

373 (G). The frequencies can be interpreted as the probability to observe the species during a one-

374 hour visit to a forest, exclosure or grazed open woodland $(0.5=50 \%$ chance) (species without

375 frequencies were observed outside the formal survey and frequencies could not be calculated).

\begin{tabular}{|c|c|c|c|c|c|c|}
\hline \multirow{2}{*}{ Nr. } & \multirow[b]{2}{*}{ Common Name } & \multirow[b]{2}{*}{ Scientific Name } & \multirow[b]{2}{*}{ Note } & \multicolumn{3}{|c|}{ Frequencies } \\
\hline & & & & $\mathbf{F}$ & EX & G \\
\hline \multicolumn{7}{|c|}{ Family: NUMIDIDAE guineafowl } \\
\hline 2 & Helmeted Guineafowl & Numida meleagris & & 0.01 & 0.05 & \\
\hline \multicolumn{7}{|c|}{ Family: PHASIANIDAE quails, francolins, stone partridge } \\
\hline 10 & Clapperton's Francolin & Francolinus clappertoni & & 0.32 & 0.30 & 0.34 \\
\hline 13 & Erckel's Francolin & Francolinus erckelii & AHB & 0.06 & & \\
\hline 15 & Common Quail & Coturnix coturnix & $P$ & & 0.09 & \\
\hline \multicolumn{7}{|c|}{ Family: ANATIDAE ducks, geese } \\
\hline 23 & Egyptian Goose & Alopochen aegyptiaca & & 0.02 & & \\
\hline \multicolumn{7}{|c|}{ Family: CICONIIDAE storks } \\
\hline 54 & Black Stork & Ciconia nigra & $P$ & & & \\
\hline 55 & Abdim's Stork & Ciconia abdimii & & & & \\
\hline 57 & White Stork & Ciconia ciconia & $P$ & & & \\
\hline 59 & Marabou (Stork) & Leptoptilos crumeniferus & & & & \\
\hline \multicolumn{7}{|c|}{ Family: THRESKIORNITHIDAE ibises, spoonbills } \\
\hline 60 & Sacred Ibis & Threskiornis aethiopicus & & & & $x$ \\
\hline 63 & Wattled Ibis & Bostrychia carunculata & $E, \mathrm{AHB}$ & $x$ & & $x$ \\
\hline \multicolumn{7}{|c|}{ Family: ARDEIDAE herons, egrets, bitterns } \\
\hline 74 & Cattle Egret & Bubulcus ibis & $(P)$ & & & $x$ \\
\hline 76 & Black-headed Heron & Ardea melanocephala & & & & \\
\hline
\end{tabular}




\begin{tabular}{|c|c|c|c|c|c|c|}
\hline \multicolumn{2}{|c|}{ Nr. Common Name } & Scientific Name & Note & \multicolumn{2}{|r|}{$\mathbf{E X}$} & G \\
\hline \multicolumn{7}{|c|}{ Family: SCOPIDAE hammerkop } \\
\hline 86 & Hammerkop (Hamerkop) & Scopus umbretta & & 0.03 & & \\
\hline \multicolumn{7}{|c|}{ Family: FALCONIDAE pygmy falcons, falcons } \\
\hline 98 & Common (Rock) Kestrel & Falco tinnunculus & $P$ & & 0.02 & 0.09 \\
\hline 111 & Peregrine (Falcon) & Falco peregrinus & $P$ & 0.02 & & \\
\hline \multicolumn{7}{|c|}{ Family: ACCIPITRIDAE snake eagles, harriers, goshawks, sparrowhawks, buzzards, eagles, etc. } \\
\hline 121 & Black (Yellow-billed) Kite & Milvus migrans & $(P)$ & 0.03 & 0.04 & \\
\hline 123 & Lammergeier (Bearded Vulture) & Gypaetus barbatus & & & & \\
\hline 138 & Pallid Harrier & Circus macrourus & $P$ & 0.02 & 0.14 & \\
\hline 139 & Montagu's Harrier & Circus pygargus & $P$ & & & $x$ \\
\hline 141 & Dark Chanting Goshawk & Melierax metabates & & 0.14 & & 0.03 \\
\hline 158 & Augur Buzzard & Buteo augur & & 0.07 & 0.05 & \\
\hline 161 & Tawny Eagle & Aquila rapax & & 0.08 & & \\
\hline 167 & African Hawk-Eagle & Hieraaetus spilogaster & & $x$ & & \\
\hline 171 & Long-crested (Hawk) Eagle & Lophaetus occipitalis & & & & \\
\hline \multicolumn{7}{|c|}{ Family: OTIDIDAE bustards } \\
\hline 180 & Black-bellied Bustard & Lissotis melanogaster & & & & 0.09 \\
\hline \multicolumn{7}{|c|}{ Family: RALLIDAE rails, flufftails, crakes, etc. } \\
\hline 188 & Rouget's Rail & Rougetius rougetii & $E$, AHB & & & \\
\hline \multicolumn{7}{|c|}{ Family: CHARADRIIDAE plovers, lapwings } \\
\hline 218 & African Wattled Plover (Wattled Lapwing) & Vanellus senegallus & & $\times$ & & \\
\hline 227 & Three-banded Plover & Charadrius tricollaris & & 0.02 & & \\
\hline \multicolumn{7}{|c|}{ Family: SCOLOPACIDAE sandpipers, stints, snipes, etc. } \\
\hline 249 & Green Sandpiper & Tringa ochropus & $P$ & $\times$ & & \\
\hline \multicolumn{7}{|c|}{ Family: PTEROCLIDIDAE sandgrouse } \\
\hline 304 & Yellow-throated Sandgrouse & Pterocles gutturalis & & 0.02 & & \\
\hline \multicolumn{7}{|c|}{ Family: COLUMBIDAE pigeons, doves } \\
\hline 309 & Speckled Pigeon (Rock Pigeon) & Columba guinea & & 0.62 & 0.21 & 0.06 \\
\hline 310 & White-collared Pigeon & Columba albitorques & $E$, AHB & 0.04 & & \\
\hline 315 & Dusky Turtle Dove (Pink-breasted Dove) & Streptopelia lugens & AHB & 0.48 & 0.04 & 0.03 \\
\hline \multicolumn{7}{|c|}{ Family: COLUMBIDAE pigeons, doves } \\
\hline 318 & (African) Mourning (Collared) Dove & Streptopelia decipiens & & 0.13 & & \\
\hline 319 & Red-eyed Dove & Streptopelia semitorquata & & $\times$ & & \\
\hline 320 & Ring-necked Dove (Cape Turtle Dove) & Streptopelia capicola & & 0.27 & & \\
\hline 321 & Vinaceous Dove & Streptopelia vinacea & & 0.44 & & \\
\hline 322 & Laughing Dove (Palm Dove) & Streptopelia senegalensis & & 0.94 & 0.75 & 0.56 \\
\hline 327 & Namaqua Dove (20.10) & Oena capensis & & 0.09 & 0.35 & 0.13 \\
\hline 328 & Bruce's Green Pigeon & Treron waalia & & 0.13 & & \\
\hline \multicolumn{7}{|c|}{ Family: PSITTACIDAE parrots, lovebirds } \\
\hline 332 & Black-winged Lovebird & Agapornis taranta & $E$, АHB & 0.22 & 0.02 & 0.06 \\
\hline \multicolumn{7}{|c|}{ Family: MUSOPHAGIDAE turacos, go-away birds, plantain-eaters } \\
\hline 336 & White-cheeked Turaco & Tauraco leucotis & AHB & & & \\
\hline 340 & Eastern Grey Plantain-Eater & Crinifer zonurus & & 0.11 & 0.04 & \\
\hline \multicolumn{7}{|c|}{ Family: CUCULIDAE cuckoos, coucals } \\
\hline 341 & Jacobin (Black-and-white, Pied) Cuckoo & Clamator jacobinus & & 0.02 & 0.05 & \\
\hline 346 & Common (Eurasian) Cuckoo & Cuculus canorus & $P$ & 0.44 & 0.30 & 0.09 \\
\hline 348 & Klaas's Cuckoo & Chrysococcyx klaas & & 0.46 & 0.02 & \\
\hline 350 & Dideric (Didric, Diederik) Cuckoo & Chrysococcyx caprius & & 0.07 & & 0.03 \\
\hline 355 & White-browed Coucal & Centropus superciliosus & & 0.01 & 0.02 & \\
\hline \multicolumn{7}{|c|}{ Family: TYTONIDAE barn owls } \\
\hline 356 & Barn Owl & Tyto alba & & & & \\
\hline Fami & TRIGIDAE true owls & & & & & \\
\hline 363 & Greyish Eagle-Owl (20.6) & Bubo cinerascens & & 0.16 & 0.09 & \\
\hline 367 & Pearl-spotted Owlet & Glaucidium perlatum & & $x$ & & \\
\hline
\end{tabular}


Family: CAPRIMULGIDAE nightjars

377 Abyssinian (Montane, Mountain) Nightjar (20.7)

Caprimulgus poliocephalus

$0.07 \quad 0.11$

Family: APODIDAE swifts, spinetails

\begin{tabular}{|c|c|}
\hline 393 & Horus Swift \\
\hline \multicolumn{2}{|c|}{ Family: COLIIDAE mousebirds } \\
\hline 395 & Speckled Mousebird \\
\hline 396 & Blue-naped Mousebird \\
\hline \multicolumn{2}{|c|}{ Family: CORACIIDAE rollers } \\
\hline 398 & Rufous-crowned (Purple) Roller \\
\hline 400 & Abyssinian Roller (20.3) \\
\hline 401 & European (Eurasian) Roller \\
\hline
\end{tabular}

Apus horus

Family: ALCEDINIDAE kingfishers

\begin{tabular}{l|l|l}
\hline 403 & Grey-headed (Chestnut-bellied) Kingfisher \\
\hline 404 & Striped Kingfisher & Ce \\
\hline 408 & (African) Pygmy Kingfisher & \\
\hline
\end{tabular}

\begin{tabular}{|l|l|}
\hline 414 & Little Bee-Eater \\
\hline 415 & Blue-breasted Bee-eater (20.8) \\
\hline 418 & White-throated Bee-eater \\
\hline 419 & Green (Little Green) Bee-Eater \\
\hline 422 & European (Eurasian) Bee-Eater \\
\hline
\end{tabular}

Family: UPUPIDAE hoopoes

$424 \quad$ (Common, Eurasian) Hoopoe (20.5)

Colius striatus

Urocolius macrourus

\begin{tabular}{l|l}
0.41 & 0.18
\end{tabular}

Coracias naevius

Coracias abyssinicus

Coracias garrulus

\begin{tabular}{l|l}
0.15 & 0.04
\end{tabular}

Family: PHOENICULIDAE wood hoopoes

\begin{tabular}{l|l|l}
\hline 426 & Black-billed Wood-Hoopoe & $P$ \\
\hline Family: BUCEROTIDAE hornbills &
\end{tabular}

\begin{tabular}{l|l}
430 & Hemprich's Hornbill (20.2) \\
432 & Red-billed Hornbill
\end{tabular}

Family: BUCORVIDAE ground hornbills

\begin{tabular}{|c|c|c|c|c|c|c|}
\hline 437 & Abyssinian (Northern) Ground Hornbill & Bucorvus abyssinicus & & 0.03 & 0.04 & 0.03 \\
\hline \multicolumn{7}{|c|}{ Family: RAMPHASTIDAE barbets, tinkerbirds } \\
\hline 438 & Red-fronted Tinkerbird & Pogoniulus pusillus & & 0.10 & & \\
\hline 442 & Banded Barbet & Lybius undatus & $E, \mathrm{AHB}$ & 0.06 & & \\
\hline 444 & Black-billed Barbet & Lybius guifsobalito & & 0.35 & & \\
\hline 447 & Yellow-breasted Barbet (20.4) & Trachyphonus margaritatus & & 0.30 & 0.25 & \\
\hline \multicolumn{7}{|c|}{ Family: PICIDAE wrynecks, woodpeckers } \\
\hline 454 & Eurasian (Northern) Wryneck & Jynx torquilla & & $\times$ & & \\
\hline 456 & Nubian Woodpecker & Campethera nubica & & 0.04 & & \\
\hline 458 & Gold-mantled (Abyssinian) Woodpecker & Dendropicos abyssinicus & $E, \mathrm{AHB}$ & 0.07 & & \\
\hline \multicolumn{7}{|c|}{ Family: PLATYSTEIRIDAE batises, wattle-eyes } \\
\hline 464 & Grey-headed Batis (Puffback Flycatcher) & Batis orientalis & & 0.30 & 0.11 & 0.03 \\
\hline \multicolumn{7}{|c|}{ Family: MALACONOTIDAE helmetshrikes, bush-shrikes, puffbacks } \\
\hline 474 & Black-crowned Tchagra (Black-headed Bush-Shrike) & Tchagra senegalus & & 0.14 & 0.53 & 0.44 \\
\hline 479 & Tropical Boubou & Laniarius aethiopicus & & 0.78 & 0.33 & \\
\hline 481 & (Northern) Brubru (Shrike) & Nilaus afer & & 0.03 & & \\
\hline \multicolumn{7}{|c|}{ Family: LANIIDAE shrikes } \\
\hline 487 & Red-backed Shrike & Lanius collurio & $P$ & 0.36 & 0.23 & 0.22 \\
\hline 488 & Isabelline (Red-tailed) Shrike & Lanius isabellinus & $P$ & & 0.09 & 0.13 \\
\hline 489 & Lesser Grey Shrike & Lanius minor & $P$ & 0.02 & 0.04 & 0.31 \\
\hline 494 & Common Fiscal (Shrike) & Lanius collaris & & 0.07 & 0.04 & 0.34 \\
\hline 495 & Woodchat Shrike & Lanius senator & $P$ & & & 0.09 \\
\hline \multicolumn{7}{|c|}{ Family: ORIOLIDAE orioles } \\
\hline 497 & Eurasian Golden Oriole & Oriolus oriolus & & 0.03 & & \\
\hline 499 & Abyssinian (Black-headed Forest) Oriole & Oriolus monacha & $E$, АHB & $\times$ & & \\
\hline
\end{tabular}

Halcyon leucocephala

Halcyon chelicuti

Ceyx pictus

\begin{tabular}{|l|r|r|}
\hline & 0.14 & \\
\hline 0.11 & & \\
\hline & & $\times$ \\
\hline
\end{tabular}

Merops pusillus
Merops variegatus
Merops albicollis
Merops orientalis
Merops apiaster

$P$

Merops apiaster

\begin{tabular}{l|l} 
Upupa epops & $P$
\end{tabular}

\begin{tabular}{|l|l|l}
0.18 & & \\
\hline 0.02 & & \\
\hline 0.05 & & \\
\hline
\end{tabular}

Phoeniculus somaliensis

Phoeniculus somaliensis

SMB

\begin{tabular}{r|r|r}
0.02 & & \\
\hline 0.40 & 0.23 & \\
\hline$\times$ & & \\
\hline 0.01 & & \\
\hline 0.02 & 0.04 & 0.22 \\
\hline
\end{tabular}

\begin{tabular}{|l|l|l|l|l|}
\hline Tockus hemprichii & SMB & 0.26 & 0.14 & 0.03 \\
\hline Tockus erythrorhynchus & & 0.05 & & \\
\hline
\end{tabular}

Family: PLATYSTEIRIDAE batises, wattle-eyes

Pogoniulus pusillus

Lybius undatus

Lybius guifsobalito

rachyphonus margaritatus

\begin{tabular}{l|l|l|}
0.28 & 0.09 & 0.03 \\
\hline
\end{tabular}


Family: DICRURIDAE drongos

\begin{tabular}{l|l}
501 & Fork-tailed (Common) Drongo
\end{tabular}

Dicrurus adsimilis

0.05

Family: MONARCHIDAE monarchs

502 African Paradise-flycatcher

Terpsiphone viridis

0.13

Family: CORVIDAE crows

507 Cape Crow (Cape Rook, Black Crow)

511 Fan-tailed Raven

Corvus capensis

Corvus rhipidurus

0.03

Family: PARIDAE tits

\begin{tabular}{l|l}
514 & Northern Black Tit
\end{tabular}

Parus leucomelas

\begin{tabular}{l|l}
$0.06 \quad 0.02$ \\
\hline
\end{tabular}

Family: HIRUNDINIDAE swallow, martins

519 Black Saw-Wing (Rough-wing)

521 Plain Martin (Brown-throated Sand-Martin)

524 Barn (Eurasian) Swallow

526 Ethiopian (Lesser Striped) Swallow

532 Northern (Common) House Martin

Psalidoprocne pristoptera

Riparia paludicola

Hirundo rustica

Hirundo aethiopica

Delichon urbicum

0.07

Family: ALAUDIDAE larks

\begin{tabular}{|c|c|c|c|c|c|c|}
\hline 542 & Flappet Lark & Mirafra rufocinnamomea & & 0.02 & 0.02 & 0.16 \\
\hline 551 & Greater Short-toed Lark & Calandrella brachydactila & $P$ & 0.05 & 0.02 & 0.25 \\
\hline 557 & Thekla (Short-crested) Lark & Galerida theklae & & 0.14 & 0.25 & 0.62 \\
\hline
\end{tabular}

Family: CISTICOLIDAE cisticolas, prinias, apalises, etc.

\begin{tabular}{|l|l|l|r|r|r|}
\hline 562 & Singing Cisticola & Cisticola cantans & 0.07 & 0.44 & 0.19 \\
\hline 566 & Winding Cisticola & Cisticola galactotes & $\times$ & \\
\hline 576 & Pectoral-patch (Pale-crowned) Cisticola & Cisticola brunnescens & & 0.04 & \\
\hline 578 & Tawny-flanked Prinia & Prinia subflava & & 0.06 & 0.14 \\
\hline 582 & Buff-bellied Warbler & Phyllolais pulchella & & 0.04 & 0.03 \\
\hline 585 & Grey-backed Camaroptera (Bleating Warbler) & Camaroptera brachyura & 0.87 & 0.84 & 0.53 \\
\hline Family: PYCNONOTIDAE bulbuls & &
\end{tabular}

\begin{tabular}{|l|l|l|l|l|l|l|}
\hline 587 & Common (Yellow-vented, Dark-capped) Bulbul & Pycnonotus barbatus & 0.76 & 0.79 & 0.56 \\
\hline
\end{tabular}
Family: SYLVIIDAE warblers

\begin{tabular}{|c|c|c|c|c|c|c|}
\hline 603 & Sedge Warbler & Acrocephalus schoenobaenus & $P$ & $x$ & & \\
\hline 607 & (Eastern) Olivaceous Warbler & Iduna pallida & $P$ & 0.27 & 0.11 & 0.19 \\
\hline 614 & Willow Warbler & Phylloscopus trochilus & $P$ & 0.31 & 0.12 & \\
\hline 615 & (Common) Chiffchaff & Phylloscopus collybita & $P$ & 0.03 & & \\
\hline 613 & Brown Woodland-Warbler & Phylloscopus umbrovirens & & 0.03 & & \\
\hline 618 & Yellow-bellied Eremomela & Eremomela icteropygialis & & & $x$ & \\
\hline 620 & Green-backed Eremomela & Eremomela canescens & SGSB & 0.11 & & \\
\hline 621 & (Northern) Crombec & Sylvietta brachyura & & 0.18 & 0.11 & \\
\hline 625 & Blackcap & Sylvia atricapilla & $P$ & 0.08 & 0.04 & \\
\hline 626 & Garden Warbler & Sylvia borin & & 0.05 & 0.02 & \\
\hline 628 & Lesser Whitethroat & Sylvia curruca & $P$ & 0.16 & 0.49 & 0.34 \\
\hline 632 & Common (Greater) Whitethroat & Sylvia communis & $P$ & 0.02 & 0.11 & 0.19 \\
\hline \multicolumn{7}{|c|}{ Family: TIMALIIDAE babblers, chatterers, catbirds } \\
\hline 644 & White-rumped Babbler & Turdoides leucopygia & SMB & 0.05 & 0.11 & \\
\hline \multicolumn{7}{|c|}{ Family: ZOSTEROPIDAE white-eyes } \\
\hline 648 & Montane (Broad-ringed) White-Eye & Zosterops poliogastrus & AHB & 0.21 & 0.16 & 0.03 \\
\hline \multicolumn{7}{|c|}{ Family: STURNIDAE starlings } \\
\hline 652 & Wattled Starling & Creatophora cinerea & & 0.02 & & \\
\hline 653 & Greater Blue-eared (Glossy) Starling & Lamprotornis chalybaeus & & 0.87 & 0.37 & 0.41 \\
\hline 662 & Violet-backed (Amethyst, Plum-coloured) Starling & Cinnyricinclus leucogaster & & 0.10 & & \\
\hline 666 & Somali Chestnut-winged Starling & Onychognathus blythii & SMB & 0.11 & & \\
\hline 668 & White-billed Starling & Onychognathus albirostris & $E$, AHB & 0.23 & & \\
\hline 672 & Red-billed Oxpecker & Buphagus erythrorhynchus & & 0.34 & & \\
\hline
\end{tabular}


Family: TURDIDAE thrushes, chats

\begin{tabular}{l|l}
675 & Groundscraper Thrush
\end{tabular}

678 Olive (Mountain, Northern Olive) Thrush

682 (Common) Nightingale

683 White-throated Robin (Irania, Persian Robin)

684 Rüppell's Robin-chat

694 Common (Eurasian) Redstart

699 Isabelline Wheatear

700 Northern Wheatear

705 Black-eared Wheatear

707 Abyssinian Black (Schalow's) Wheatear

712 Blackstart (Black-tailed Rock Chat)

714 Rüppell's (Black) Chat

716 Mocking (White-shouldered) Cliff Chat

717 White-winged Cliff Chat

718 (Common, Rufous-tailed) Rock Thrush

719 Little Rock-Thrush

Family: MUSCICAPIDAE flycatchers

Pale (Pallid) Flycatcher

Spotted Flycatcher

African Dusky Flycatcher

730 Semi-collared (Half-collared) Flycatcher

Family: NECTARINIIDAE sunbirds

\begin{tabular}{|l|l|}
\hline 736 & Scarlet-chested Sunbird \\
\hline 738 & Tacazze Sunbird \\
\hline 742 & Mariqua (Marico) Sunbird \\
\hline 746 & Variable (Yellow-bellied) Sunbird \\
\hline
\end{tabular}

Family: PASSERIDAE sparrows and petronias

\begin{tabular}{l|l|l}
\hline 749 & Chestnut-crowned Sparrow-weaver & $P$ \\
\hline 756 & Grey-headed (Swainson's) Sparrow & $P$
\end{tabular}

Family: PLOCEIDAE weavers and relatives

\begin{tabular}{|l|l|}
\hline 765 & Speckle-fronted Weaver \\
\hline 767 & Baglafecht Weaver \\
\hline 772 & Rüppell's Weaver \\
\hline 777 & Village (Black-headed) Weaver \\
\hline 789 & Northern Red Bishop \\
\hline 792 & Yellow-mantled (Yellow-shouldered) Widowbird \\
\hline 794 & Red-collared (Red-naped) Widowbird \\
\hline
\end{tabular}

794 Red-collared (Red-naped) Widowbird

Family: ESTRILDIDAE waxbills, firefinches

\begin{tabular}{|c|c|c|c|c|c|c|}
\hline 798 & Cut-throat (Finch) & Amadina fasciata & & 0.02 & & 0.03 \\
\hline 802 & Red-billed Firefinch & Lagonosticta senegala & & 0.41 & 0.25 & 0.03 \\
\hline 806 & Red-cheeked Cordon-bleu & Uraeginthus bengalus & & 0.88 & 0.84 & 0.59 \\
\hline 809 & Yellow-bellied Waxbill (East African Swee) & Estrilda quartinia & $\mathrm{AHB}$ & & & \\
\hline 811 & Crimson-rumped Waxbill & Estrilda rhodopyga & & 0.15 & & \\
\hline 817 & African (Warbling) Silverbill & Lonchura cantans & & 0.02 & 0.05 & \\
\hline \multicolumn{7}{|c|}{ Family: VIDUIDAE indigobirds, whydahs } \\
\hline 822 & Village (Common) Indigobird & Vidua chalybeata & & 0.12 & & \\
\hline 826 & Pin-tailed Whydah (20.9) & Vidua macroucra & & 0.10 & 0.02 & \\
\hline \multicolumn{7}{|c|}{ Family: MOTACILLIDAE wagtails, pipits, longclaws } \\
\hline 833 & Yellow Wagtail & Motacilla flava & $P$ & & & \\
\hline 835 & Grey Wagtail & Motacilla cinerea & $P$ & & & \\
\hline 838 & African Pied Wagtail & Motacilla aguimp & & & & \\
\hline
\end{tabular}




\begin{tabular}{|c|c|c|c|c|c|c|}
\hline \multirow{2}{*}{\multicolumn{7}{|c|}{$\begin{array}{l}\text { Nr. } \quad \text { Common Name } \\
\text { Family: TURDIDAE wagtails, pipits, longclaws (continued) }\end{array}$}} \\
\hline & & & & & & \\
\hline \multicolumn{2}{|c|}{ Family: TURDIDAE wagtails, pipits, longclaws (continued) } & Anthus campestris & $P$ & 0.03 & 0.02 & 0.16 \\
\hline 844 & Plain-backed Pipit & Anthus leucophrys & & 0.02 & 0.04 & 0.19 \\
\hline 845 & Tree Pipit & Anthus trivialis & $P$ & 0.01 & & 0.03 \\
\hline \multicolumn{7}{|c|}{ Family: FRINGILLIDAE canaries, siskins, seedeaters } \\
\hline 848 & Yellow-crowned Canary & Serinus canicollis & & & & $x$ \\
\hline 850 & African Citril & Serinus citrinelloides & AHB & 0.04 & & 0.03 \\
\hline 854 & White-throated Seedeater & Serinus xanthopygius & $E$ & 0.38 & 0.26 & 0.28 \\
\hline 861 & Brown-rumped Seedeater & Serinus tristriatus & AHB & 0.04 & & 0.06 \\
\hline 863 & Streaky Seedeater & Serinus striolatus & AHB & 0.06 & 0.02 & 0.03 \\
\hline \multicolumn{7}{|c|}{ Family: EMBERIZIDAE buntings } \\
\hline 865 & Ortolan (Bunting) & Emberiza hortulana & $P$ & 0.15 & 0.07 & 0.03 \\
\hline 868 & Cinnamon-breasted (Rock) Bunting & Emberiza tahapisi & & 0.28 & 0.68 & 0.72 \\
\hline 870 & Golden-breasted Bunting & Emberiza flaviventris & & 0.13 & & \\
\hline
\end{tabular}

